\title{
Profissional em saúde, amador em educação
}

Paulo Barata

De um professor de saúde pública pede-se competência na sua área específica de conhecimento. Seja em planejamento, epidemiologia, qualquer que seja, esta competência é formalmente atestada pelos títulos que possui mestrado, doutorado - e medida (é o que se supõe) de maneiras diversas, como, por exemplo, pelo número de trabalhos que publica. Títulos conquistados e pesquisas realizadas significam (outra vez, é o que se supõe) um conhecimento adquirido e praticado com estudo e rigor, um conhecimento sólido, em suma. Um dos significados da palavra "professor" (Novo Dicionário Aurélio, 1̣̣ edição) é "homem perito ou adestrado".

Fazem parte das atividades do professor dar aulas, orientar alunos, organizar cursos. Atividades pedagógicas: ensinar, trabalhar o próprio conhecimento, transmiti-lo da melhor forma. Nestas atividades, o professor titulado, o pesquisador competente, é, em geral, um amador. Aprende por conta própria, na sua prática diária, com seus acertos e erros, até onde seu interesse e sua sensibilidade o permi. te $m$. Um improviso que seria inaceitável na sua prática especifica em saúde pública. De modo geral, o professor do ensino superior ( e não só da saúde pública) não estudou para ser professor: ele estudou me dicina, ou sociologia, ou estatística, e, por algum caminho, por alguma contingência, exerce a atividade de professor, trabalha em educação. Sua formação não inclui o estudo da educação, da filosofia, da didática. embora a sua atuação no ensino delas dependa, mesmo que ele não tenh a disto maior consciência.

Se epidemiologia, planejamento ou outras áreas da saúde pública são assuntos que se estudam, que requerem um aprendizado, também é assim com a educação. A educação possui uma história longa - era já uma preocupação central dos gregos antigos. Tem a sua filosofia, com diversas escolas e ideologias, e o seu lado técnico, que estuda e elabora alternativas para o processo de ensino e de aprendizagem. Existe todo um debate sobre a relação da educação com o social e o político, sobre a sua prática como meio de transformação do homem e da soçedade e sobre a sua concepção como um objetivo a ser alcançado por cada cidadão e pela sociedade como um todo. Por lidar com pessoas, pelo aspecto de contato humano que envolve, a educação terá sempre um lado de arte e de envol- 
vimento pessoal que, como diz a letra de Noel Rosa, "ninguém aprende no colégio". No entanto, estudo e refle. xão melhoram e dão consistência à sua prática. No Brasil, existem centros de qualidade na área da educação e publicações (revistas e livros) que deveriam ser do conhecimento de qualquer professor.

O ensino da saúde pública está na interseção da saúde com a educação. O conhecimen to técnico e o discernimento político na área da saúde devem estar combinados a uma competência em educação se se deseja um ensino eficaz da saúde pública. Este ensino, geralmente feito em nível de pós-graduação, é parte de um sistema educacional formal - escolas, universidades - e de um processo de aprendizagem sofrido (esta é a palavra!) pelos estudantes e que precisam ser compreendidos e el aborados pelo professor. Da mesma forma como é preciso uma saúde pública que atenda às nossas necessidades, é preciso também um ensino que atenda às nossas necessidades, que responda às necessidades colocadas pela prática complexa da saúde pública e aos desejos de crescimento dos estudantes. Este ensino demanda estudo e pesquisa em educação.

Esta questão não pertence. claro, apenas à saúde pública, sendo válida igualmente para professores de matemática ou de medicina. Ela reflete a pouca atenção que a un!versidade dedica à formação humanística dos profissionais que por ela passam, o que é especialmente sentido no caso dos professores, e a tradição de desprezo que existe no Brasil em relação à educação. Neste país, a educação é. por si, um problema tão fundamental e gigantesco quanto a saúde pública. O nosso sistema educacional tem reconhect. damente deficiéncias sérias em todos os níveis. e a pósgraduação em saúde pública, pelo ensino que pratıca e pe. los professores que forma nos seus programas de mestrado e doutorado, tem o que contribuir para a melhora desse sistema.

Por parte das universidades - e das escolas de saúde pública - é necessár o que haja uma valorização das atividades relacionadas ao ensino, frequentemente encaradas como secundárias em relação à pesquisa. Esta valorização precisa se expressar de modo concreto: tempo, recursos materais, est imulos e reconhecimento de toda ordem ao trabalho em ensino. No entanto, universidades e escolas, sendo instituiçōes, são em certa medida abstrações: elas existem e se orientam segundo os valores e critérios das pessoas que as compõem. Neste sentido, dar atenção à educação como área de estudo e pesquisa deveria ser uma preocupação de todo (assim denominado) professor que se pretenda profissional do ensino. 